\title{
Factors regulating ovulation rate in the ewe
}

\author{
R. J. Scaramuzzi and H. M. Radford \\ CSIRO, Division of Animal Production, PO Box 239, Blacktown, New South Wales 2148, Australia
}

Our knowledge of ovulation rate is still very rudimentary, but that is not to say that little information is available. The literature contains a vast body of data on the subject (Cumming, 1977) but a general model, such as those that are now widely accepted for the control of the oestrous cycle (Baird \& McNeilly, 1981) or of seasonal reproduction (Goodman \& Karsch, 1981), is not available.

The ovulation rate of eutherian mammals is defined in two ways: (1) as the average number of eggs released in animals that ovulate, but this definition cannot produce an ovulation rate of less than 1.0 as it makes no allowance for anovulatory animals which should then be reported as a separate datum; and (2) as the average number of eggs released in a group of animals-this definition includes anovulatory animals and therefore can give values of less than 1.0. The physiological requirement for ovulation probably differs from that which regulates the number of follicles which do ovulate. For this reason the first definition is preferred, and the ovulation rate values reported in this paper have been calculated on this basis.

The number of eggs shed at ovulation varies widely both within and between mammalian species (Asdell, 1964). The underlying causes can be both genetic and environmental. Furthermore, in many scientific reports these two general factors are very often confounded. The problem is further complicated by the presence of interactions between genotype and the environment in the expression of ovulation rate (Land, 1977; Gunn \& Doney, 1979). The use of experimental animals of known genetic backgrounds maintained under defined and controlled environmental conditions is seen as essential to the study of ovulation rate.

\section{Factors affecting ovulation rate}

Numerous environmental and physiological factors have been reported to influence ovulation rate. In sheep this can be best seen as marked variation within and between breeds of sheep.

\section{Genetic variation}

The vast majority of domesticated breeds of sheep have ovulation rates of between 1 and 2 . However, at least 5 breeds are known in which the ovulation rate approaches or may exceed 3 (Table 1). The increased ovulation rate is mostly accompanied by an increased variability in the number of ovulations and individual animals with 5 and 6 or more ovulations have been reported (Bradford, Quirke \& Hart, 1971; Lahlou-Kassi \& Marie, 1981; Bindon \& Piper, 1982). These breeds of sheep, usually referred to as the high-fecundity breeds, are a valuable genetic resource and can be used to improve the fecundity (i.e. litter size) of indigenous sheep by cross breeding (Quirke, 1978, 1979). Ovulation rate is a characteristic that displays a considerable degree of genetic variation and the published estimates for its heritability (Hanrahan, 1980) show that it can be increased by genetic selection. For those interested in the mechanisms regulating ovulation rate the high-fecundity breeds of sheep allow a comparative approach to the problem. 
Table 1. The known breeds of sheep with high ovulation rates

\begin{tabular}{|c|c|c|c|}
\hline Breed & Origin & $\begin{array}{c}\text { Ovulation rate } \\
\text { (mean } \pm \text { s.e.m.) }\end{array}$ & Reference \\
\hline Booroola Merino & Australia & $2.68+0.11$ & Bindon et al. (1978) \\
\hline Dahman & Morocco & $2.50 \pm 0.45$ & Lahlou-Kassi \& Marie (1981) \\
\hline Finn & Finland/Russia & $3.31 \pm 0.17$ & Bradford et al. (1971) \\
\hline Hu Yang & China & $3.11 \pm 0.18$ & Guo et al. (1981) \\
\hline Romanov & Russia & $2.86 \pm 0.23$ & Bindon et al. (1979) \\
\hline
\end{tabular}

\section{Nutrition}

The age-old practice of flushing, that is of mating ewes while they are increasing in body weight, is in fact recognition of a relationship between nutrition and ovulation rate. There is much literature dating back about 80 years (Marshall, 1903) on the subject. Regrettably, most of this literature, although it seems to describe the phenomenon adequately, is not very helpful in explaining the mechanism of the response. Over the past 7 years some progress has been made in our understanding of the complex interrelationships between nutrition, body weight and ovulation rate. In 1975, Knight, Oldham \& Lindsay reported that ewes fed a supplement of lupin grain could

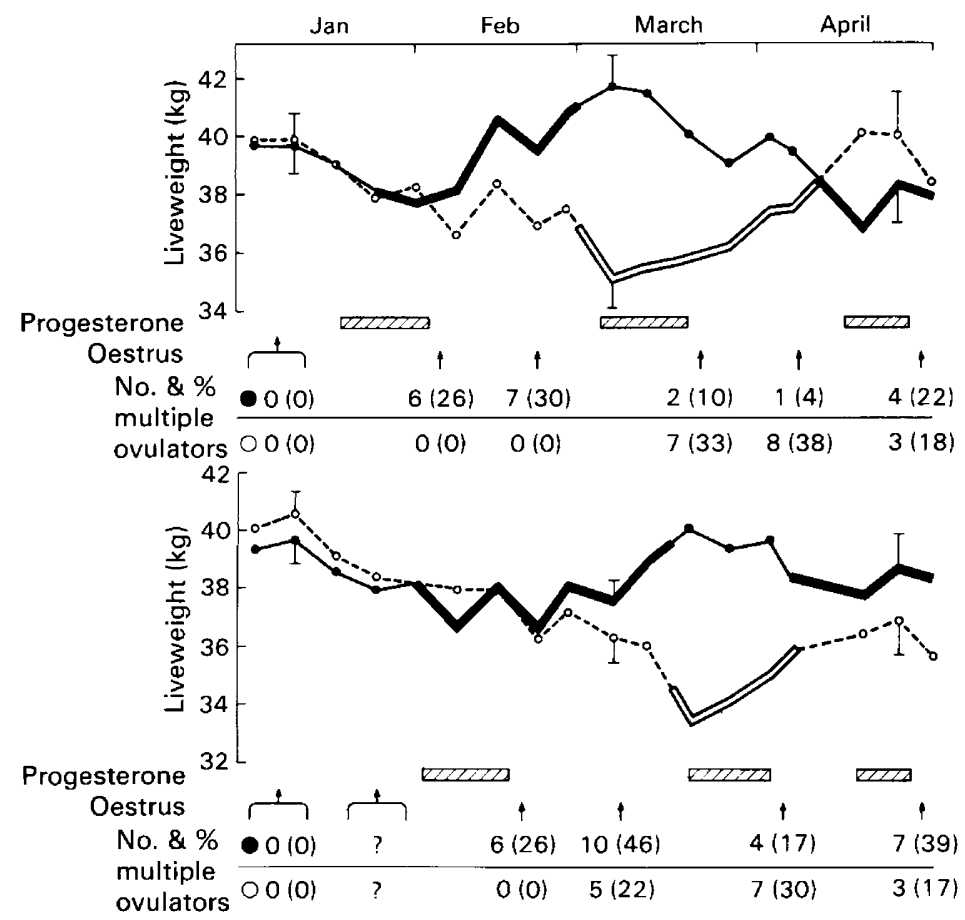

Text-fig. 1. Changes in body weight and incidence of multiple ovulations in 4 groups of ewes $(N=25-30)$ fed a basal diet of wheaten chaff supplemented at intervals with lupin grain. Thin lines indicate periods of feeding with wheaten chaff only and thick lines indicate periods of lupin grain supplementation. The bars indicate periods of oestrous synchronization using Silestrus implants and the arrows indicate times of oestrus. The number and percentage of multiple ovulations are indicated for each group at each endoscopy. Data from Radford et al. (1980). 
respond in about 1 week with an increase of about $30 \%$ in the number of twin ovulations. Subsequent work, principally in Australia and New Zealand, has confirmed that ewes can respond to short-term changes in protein and energy availability with an increased number of twin ovulations. The following experiment (Radford, Donegan \& Scaramuzzi, 1980) illustrates the nature of the response to lupin supplementation. Four groups of Merino ewes were held indoors in pens and fed either wheaten chaff ( $750 \mathrm{~g} /$ ewe/day) or wheaten chaff supplemented with $500-700$ $\mathrm{g} /$ ewe/day of lupin grain over a 16-week period. The lupin grain supplement was fed to different groups at different times as shown in Text-fig. 1. The animals were weighed weekly and the ovulation rates recorded periodically using a laparoscopic technique. The oestrous cycles of the ewes were re-synchronized every 2-3 cycles using Silestrus implants (Abbott Laboratories, Chicago, Illinois, U.S.A.). In general, this experiment confirms the findings of Knight et al. (1975) and, in addition, indicates that the responses are rapidly reversible, suggesting a short-term ovarian response to the additional feeding. The response to lupin feeding can occur in as short a time as 6 days (Oldham, 1980). A group of 800 Merino ewes having regular unsynchronized oestrous cycles and in the presence of harnessed, vasectomized rams were fed a daily lupin supplement of 750 $\mathrm{g} /$ ewe/day. On each subsequent day those animals mating in the preceding $24 \mathrm{~h}$ were identified and their ovulation rates determined by laparoscopy about 1 week later. In this way the time course of any ovarian response associated with the lupin supplement could be accurately determined. The ewes showed a sudden increase in ovulation rate after 6 days of lupin feeding, with no additional increase beyond that time (Text-fig. 2). The other important feature of these data is the lack of a change in body weight over the period of lupin feeding, suggesting a response to nutrient supply that is independent of body weight change or body weight per se (Lindsay, 1976).

Not all observers have reported stimulatory responses to energy/protein supplements and it seems probable that ewes in good body condition and/or on a good quality basal ration will not respond to additional feeding. Smith, Jagusch \& Farquhar (1981) showed that protein intakes of around $200 \mathrm{~g} /$ day produced a maximum increase in ovulation rate with no additional response to further increases in either energy or protein intake (Table 2).

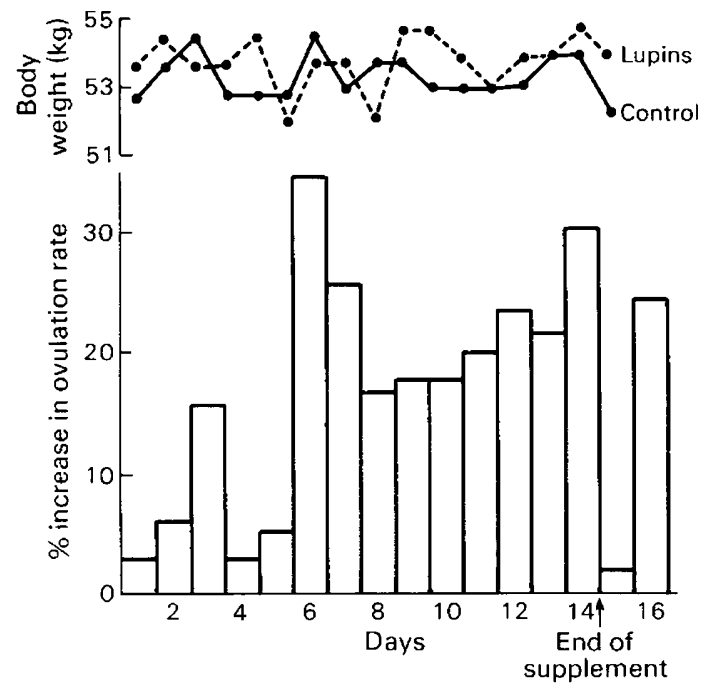

Text-fig. 2. The body weight of two groups of randomly cycling Merino ewes $(N=800)$ at pasture. One group was supplemented with lupin grain (lupins), $750 \mathrm{~g} / \mathrm{ewe} / \mathrm{day}$, the other group was not supplemented (controls). The lower panel shows the percentage increase in ovulation rate of the lupin-supplemented group of ewes over the control group for ewes ovulating on each day from the start of lupin grain supplementation. Oestrus was detected using harnessed vasectomized rams and ovulation rate was determined at laparoscopy about 1 week after oestrus. From Oldham (1980) with permission. 
Table 2. The mean ovulation rates of 16 groups of Coopworth sheep (50/group) fed four isocaloric diets containing different levels of crude protein, at four levels of dry matter intake (taken from Smith et al., 1981)

\begin{tabular}{llrrrr}
\hline & & \multicolumn{4}{c}{ Feed intake } \\
\multirow{2}{*}{$\begin{array}{c}\text { \% Crude } \\
\text { protein }\end{array}$} & & (kg dry matter/ewe/day) \\
\cline { 3 - 6 } & & 0.5 & 1.0 & 1.5 & 2.0 \\
\hline \multirow{2}{*}{12} & Ovulation rate & 1.26 & 1.23 & 1.23 & 1.62 \\
& Protein intake (g/day) & 60 & 120 & 180 & 240 \\
15 & Ovulation rate & 1.13 & 1.23 & 1.54 & 1.47 \\
& Protein intake (g/day) & 75 & 180 & 225 & 300 \\
& Ovulation rate & 1.04 & 1.12 & 1.41 & 1.51 \\
& Protein intake (g/day) & 90 & 180 & 270 & 360 \\
& Ovulation rate & 1.22 & 1.46 & 1.51 & 1.66 \\
& Protein intake (g/day) & 110 & 220 & 330 & 440 \\
& & & & & \\
\hline
\end{tabular}

The absolute body weight of ewes at mating and the relative rate of change of body weight immediately before mating are also associated with increased multiple ovulation (Coop, 1966). After careful re-analysis of the existing literature it was concluded that a clear relationship existed between liveweight and ovulation rate (Morley, White, Kenney \& Davis, 1978). These authors calculated that each additional kilogram liveweight is usually associated with a $2 \cdot 0-2.5 \%$ increase in ovulation rate at an autumn mating. How widely applicable this relationship is we cannot say, but it does give us some idea of the complex interrelationships between liveweight, level of feeding and ovulation rate. A further complicating factor in our understanding also arises from reports that the ovulation rate at one time is correlated with nutritional events (and bodyweight changes) occurring some months earlier (Fletcher, 1974; Cahill, 1981). Such responses may well represent an immediate effect of nutrition on the population of small follicles within the ovary.

\section{Time of year}

It has been known for many years that ovulation rate varies with time of year (McKenzie \& Terrill, 1937; Land, Pelletier, Thimonier \& Mauléon, 1973). This effect has usually been observed in pasture-fed animals and much of the data consequently are confounded with the effects of nutrition and liveweight. However, variations in ovulation rate with time of year have also been observed in pen-fed animals on a constant diet (Radford, 1959; Dun, Ahmed \& Morrant, 1960). This effect has been demonstrated in many breeds of sheep and over a wide range of environmental conditions and the results of two recent studies are shown in Text-fig. 3. The features to emerge are that ovulation rate is highest in the late summer and autumn, i.e. at the start of the natural breeding season, and declines progressively during the late autumn and winter to reach a minimum just before the ewes become anoestrous. Responses to season were not seen in maiden ewes (Fletcher, Geytenbeek \& Allden, 1970) or in adult ewes with very low liveweights (Fletcher, 1971). In these situations ovulation rate is suppressed by other factors and no additional suppression can be observed as the breeding season progresses. The common factor in all of these studies is season, and as photoperiod affects the seasonality of breeding it has been suggested that photoperiod also affects ovulation rate.

\section{Social factors}

In Merino sheep the introduction of rams to seasonally anovulatory ewes will cause the ewes to ovulate provided that the ewes have previously been isolated from rams (Underwood, Shier \& 


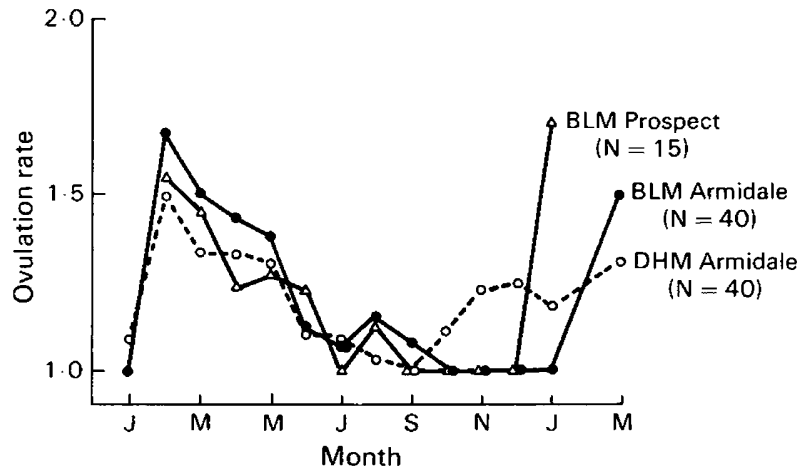

Text-fig. 3. The ovulation rate of 3 groups of ewes at different times of year and at 2 locations (Armidale, NSW; Prospect, NSW). BLM = Border Leicester Merino cross ewes; DHM = Dorset Horn Merino cross ewes. The breeding season in these environments extends from February to July. Unpublished data of J. Thimonier, B. M. Bindon, L. R. Piper, R. J. Scaramuzzi \& J. A. Downing.

Davenport, 1944). This phenomenon, now commonly referred to as 'the ram effect', occurs in several breeds of sheep (Martin \& Scaramuzzi, 1983). The induced ovulation seen in such sheep is accompanied by an increased ovulation rate (Table 3). The increased number of multiple ovulations accompanying the 'ram effect' can be exploited if concomitant oestrus is induced by a period of progestagen priming (Robinson, 1954; Reeve \& Chamley, 1982; Martin \& Scaramuzzi, 1983).

Table 3. The ovulation rate in ewes induced to ovulate by association with rams (taken from Oldham, 1980)

\begin{tabular}{|c|c|c|c|c|c|c|}
\hline \multirow[b]{2}{*}{ Date } & \multirow{2}{*}{\multicolumn{2}{|c|}{$\begin{array}{c}\text { No. } \\
\text { of ewes }\end{array}$}} & \multicolumn{3}{|c|}{ Distribution of $\mathrm{CL}$} & \multirow{2}{*}{$\begin{array}{l}\text { Ovulation } \\
\text { rate }\end{array}$} \\
\hline & & & 0 & 1 & 2 & \\
\hline \multirow[t]{2}{*}{ October } & (a) & 119 & 94 & 24 & 1 & $1 \cdot 04$ \\
\hline & (b) & 29 & 0 & 19 & 10 & $1 \cdot 34$ \\
\hline November & (c) & 29 & 8 & 20 & 1 & 1.05 \\
\hline
\end{tabular}

(a) Examined before introduction of rams.

(b) Sample of anovulatory ewes from group (a), placed with vasectomized rams 2 days after laparoscopy and examined again 6 days later.

(c) The same 29 ewes as in (b) examined one cycle later.

Age and parity

In many studies the effects of age and parity are confounded. The maiden ewe in her first breeding season has a lower ovulation rate than do older ewes (McKenzie \& Terrill, 1937). However, the lower body weight of maiden ewes together with other differences in their nutrition further confounds this relationship. 


\section{Exogenous hormones}

Exogenously administered reproductive hormones will affect ovulation rates. Ovulation rate can be increased by the administration of gonadotrophins such as pregnant mare serum gonadotrophin (PMSG) (Robinson, 1951; Gherardi \& Lindsay, 1980), crude extracts of pituitary glands (Moore \& Shelton, 1964), follicle-stimulating hormone (FSH) (Laster, 1973; Wright, Bondioli, Grammer, Kuzan \& Menino, 1981; Bondioli \& Wright, 1981) and possibly luteinizing hormone (LH). The ovarian steroid hormones also affect ovulation rate. Progestagens suppress ovulation altogether, although it is not known whether smaller doses that do not block ovulation have any effect on ovulation rate. Oestrogens such as oestradiol benzoate (Land, 1976) and the phyto-oestrogen coumestrol (Smith, Jagusch, Brunswick \& Kelly, 1979) will depress ovulation rate. This effect is thought to be due to the oestrogens limiting the secretion of gonadotrophins (Land, 1976).

\section{Steroid antibodies}

A number of years ago we were able to demonstrate that passive or active immunization against oestrogens or androgens could increase the ovulation rate of treated sheep (Text-fig. 4). Ewes passively immunized against oestradiol-17 $\beta$ over the last 5 days of the oestrous cycle responded with a doubling of their ovulation rate (Scaramuzzi, 1976), illustrating the rapidity of the response and suggesting a rapid effect on the final stages of follicle growth and development. Active immunization against androstenedione (Scaramuzzi, Davidson \& Van Look, 1977), testosterone, oestrone, oestradiol-17ß (Martensz, 1977; Scaramuzzi, Martensz \& Van Look, 1980a; Scaramuzzi, Baird, Clarke, Martensz \& Van Look, 1980b; Scaramuzzi, Baird, Martensz, Turnbull \& Van Look, 1981b) and progesterone (Hoskinson, Scaramuzzi, Downing, Hinks \& Turnbull, 1982b) have all been reported to increase ovulation rate in sheep. The effects of steroid immunity on ovulation rate may form the basis of methods to increase the lambing rate of commercial flocks (Scaramuzzi, Cox \& Hoskinson, 1982; Land, Morris, Baxter, Fordyce \& Forster, 1982).
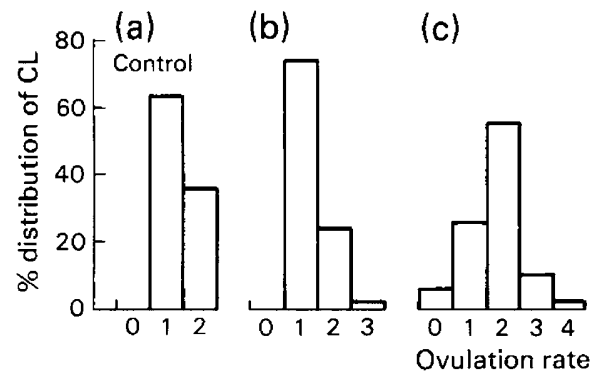

(d)

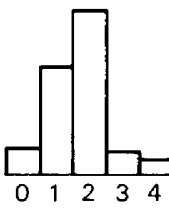

(e)

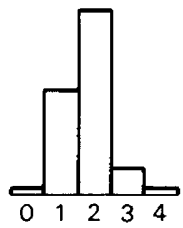

Text-fig. 4. The percentage distributions of ovulation in groups of ewes $(N=50$ /group) immunized against (b) human serum albumin (HSA), (c) androstenedione-7-HSA, (d) oestrone-6-HSA and (e) androstenedione-11-BSA. Adapted from Cox et al. (1982).

\section{Hormonal correlates of ovulation rate}

All of the factors which change ovulation rate have been thought to act through the effects of pituitary gonadotrophins on the growth and maturation of ovarian follicles. While this remains a strong possibility it cannot be assumed that the endocrine system is the sole regulator of ovulation rate; nevertheless the list of hormone preparations known to alter ovulation rate is considerablegonadotrophins, releasing factors, steroids, antioestrogens. Some of the factors which affect ovulation rate, such as time of year or the sudden introduction of rams, at present can only be satisfactorily explained by actions involving the hypothalamo-pituitary system and its hormones. 
Likewise, mammals with two functional ovaries can ovulate one or more follicles from either or both ovaries, a fact difficult to explain without the involvement of the endocrine system. For example, how can the removal of one ovary alter the ovulation rate of the remaining ovary?

Consequently, it is hardly surprising that a considerable effort has gone into attempts to uncover the hormonal correlates of ovulation rate. It is widely believed (perhaps wrongly) that a knowledge of the hormonal correlates of ovulation rate will rapidly lead to a better understanding of ovulation rate and its control mechanism(s). We have used three different models of physiological situations in which reproducible differences in ovulation rate were expected and have then measured some of the steroid and gonadotrophin hormones thought to be important in regulating ovulation rate. These models are (1) ewes with genetically determined differences in ovulation rate; (2) ewes with differences in ovulation rate associated with energy/protein supplements; and (3) ewes in which ovulation rate had been increased by immunization against steroids.

\section{Steroid and gonadotrophin levels during the oestrous cycle of the Booroola Merino}

Five Booroola Merino ewes and 5 control Merino ewes were cannulated (jugular vein) and blood sampled on Days 2 (after ovulation), 9 (mid-luteal), and 16 (pre-ovulatory) of the oestrous cycle. Blood sampling on each day consisted of collecting a sample every 15 min over a 6 -h period. Radioimmunoassays were carried out on the plasma for LH (Martensz, Baird, Scaramuzzi \& Van Look, 1976), FSH (Walton, McNeilly, McNeilly \& Cunningham, 1977), oestradiol-17 (Scaramuzzi \& Land, 1978) and androstenedione (Baird, Burger, Heavon-Jones \& Scaramuzzi, 1974). Ovulation rates were also determined at the mid-luteal phase of the oestrous cycle after blood sampling. The results of all of these hormone analyses are presented in Tables 4 and 5 . No differences were noted in any of the hormone levels or patterns, with the exception of elevated levels of androstenedione during the peri-ovulatory period of the Booroola Merino (Days 2 and 16). The significance of these elevated levels of androstenedione is not clear but may be related to a reduced ability of the granulosa cells to aromatize androgen precursors. The release of LH was pulsatile and was associated with a pulsatile pattern of oestradiol levels (Text-fig. 5). The frequency of $\mathrm{LH}$ pulses did not differ between the two types of ewe, although it did vary according to the stage of the oestrous cycle (Table 5).

Table 4. The mean \pm s.e.m. concentrations of androstenedione and oestradiol-17 $\beta$ in jugular venous plasma of Booroola Merino and control Merino ewes at 3 stages of the oestrous cycle (R. J. Scaramuzzi, unpublished data)

\begin{tabular}{|c|c|c|c|}
\hline \multirow{2}{*}{$\begin{array}{c}\text { Day of } \\
\text { oestrous } \\
\text { cycle }\end{array}$} & \multirow[b]{2}{*}{ Steroid } & \multicolumn{2}{|c|}{ Steroid conc. $(\mathrm{pg} / \mathrm{ml})$} \\
\hline & & $\begin{array}{l}\text { Booroola } \\
\text { Merino }\end{array}$ & $\begin{array}{l}\text { Control } \\
\text { Merino }\end{array}$ \\
\hline \multirow[t]{2}{*}{2} & Androstenedione & $10 \cdot 8 \pm 10 \cdot 1$ & $4.9 \pm 2 \cdot 2$ \\
\hline & Oestradiol & $0.58 \pm 0.13$ & $0.50 \pm 0.15$ \\
\hline \multirow[t]{2}{*}{9} & Androstenedione & $6 \cdot 1 \pm 2 \cdot 4$ & $4 \cdot 6 \pm 2 \cdot 3$ \\
\hline & Oestradiol & $0.53 \pm 0.16$ & $0.67 \pm 0.14$ \\
\hline \multirow[t]{2}{*}{16} & Androstendione & $18 \cdot 2 \pm 7 \cdot 2$ & $9 \cdot 4 \pm 2 \cdot 6$ \\
\hline & Oestradiol & $1.14 \pm 0.41$ & $1.63 \pm 0.63$ \\
\hline
\end{tabular}

Five animals/group were bled every $30 \mathrm{~min}$ for $3 \mathrm{~h}$ on each occasion.

Mean ovulation rates: Booroola $3 \cdot 4$, Control $1 \cdot 2$. 
Table 5. The mean \pm s.e.m. concentrations of $\mathrm{LH}$ and FSH in jugular venous plasma and the frequency of LH pulses (presented as pulse intervals) in Booroola Merino and control Merino ewes at 3 stages of the oestrous cycle (R. J. Scaramuzzi, H. M. Radford \& M. A. Hillard, unpublished data)

\begin{tabular}{|c|c|c|c|c|}
\hline & \multirow{2}{*}{$\begin{array}{l}\text { Type of } \\
\text { ewe }\end{array}$} & \multicolumn{3}{|c|}{ Day of oestrous cycle } \\
\hline & & 2 & 9 & 16 \\
\hline \multirow[t]{2}{*}{ Mean LH (ng/ml) } & Booroola & $2 \cdot 4 \pm 1 \cdot 2$ & $1 \cdot 3 \pm 0 \cdot 7$ & $1.6 \pm 1 \cdot 3$ \\
\hline & Control & $2.3 \pm 0.5$ & $1.4 \pm 0.4$ & $1.6 \pm 0.2$ \\
\hline \multirow[t]{2}{*}{ Pulse interval (min) } & Booroola & $60.0 \pm 0.0$ & $216.0 \pm 53.6$ & $152.0 \pm 82.0$ \\
\hline & Control & $61.6 \pm 11.5$ & $216.0 \pm 53.6$ & $73.6 \pm 28.4$ \\
\hline \multirow[t]{2}{*}{ Mean FSH (ng/ml) } & Booroola & $55.0 \pm 18.2$ & $53.1 \pm 25.5$ & $41 \cdot 1 \pm 17 \cdot 1$ \\
\hline & Control & $61.1 \pm 17.8$ & $67.9 \pm 15.3$ & $39.8 \pm 10 \cdot 6$ \\
\hline
\end{tabular}

Five animals/group were bled every $15 \min$ for $6 \mathrm{~h}$ on each occasion.

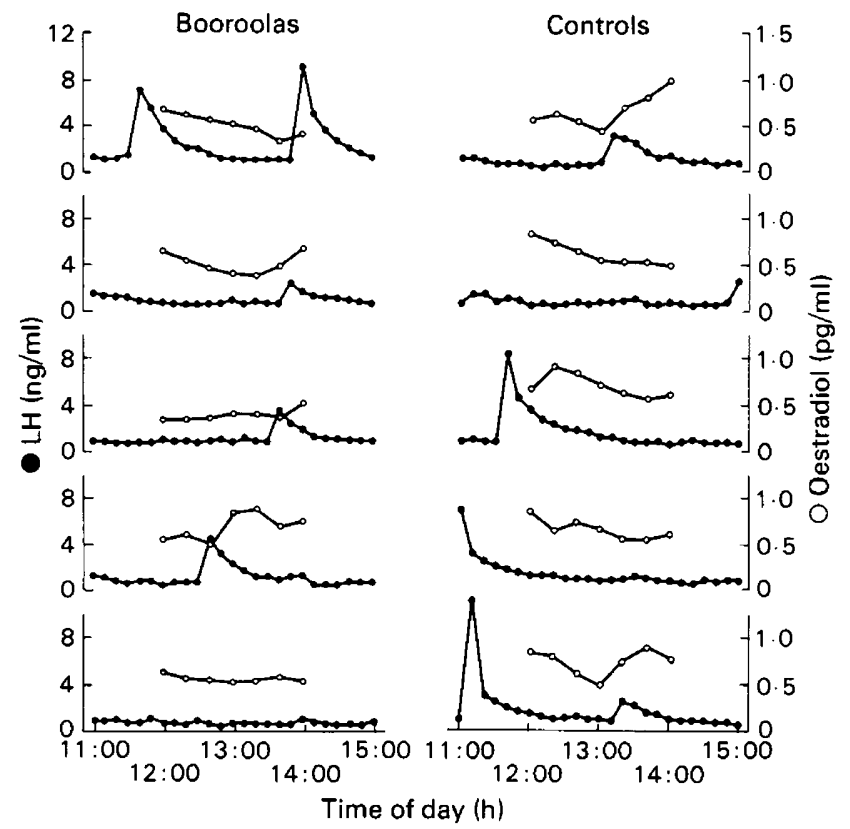

Text-fig. 5. Concentrations of $\mathrm{LH}$ and oestradiol-17 $7 \beta$ in jugular venous blood from 5 Booroola Merino ewes and 5 control Merino ewes. The ewes were sampled on Day 9 of the oestrous cycle, at 15-min intervals for $6 \mathrm{~h}$. LH levels were measured in all samples while oestradiol-17 $\beta$ levels were measured in every 2 nd sample over the middle $3 \mathrm{~h}$ period. (R. J. Scaramuzzi \& H. M. Radford, unpublished data.)

\section{LH levels during the follicular phase of the oestrous cycle}

Ewes $(\mathrm{N}=20)$ selected from those described earlier (Text-fig. 1) were cannulated and blood sampled every $15 \mathrm{~min}$ for $60 \mathrm{~h}$ from the time of progesterone implant removal. LH and FSH were measured by radioimmunoassays. Typical patterns of LH levels are illustrated for ewes with a single (Text-fig. 6a) or a twin ovulation (Text-fig. 6b). When all the single and multiple ovulating 


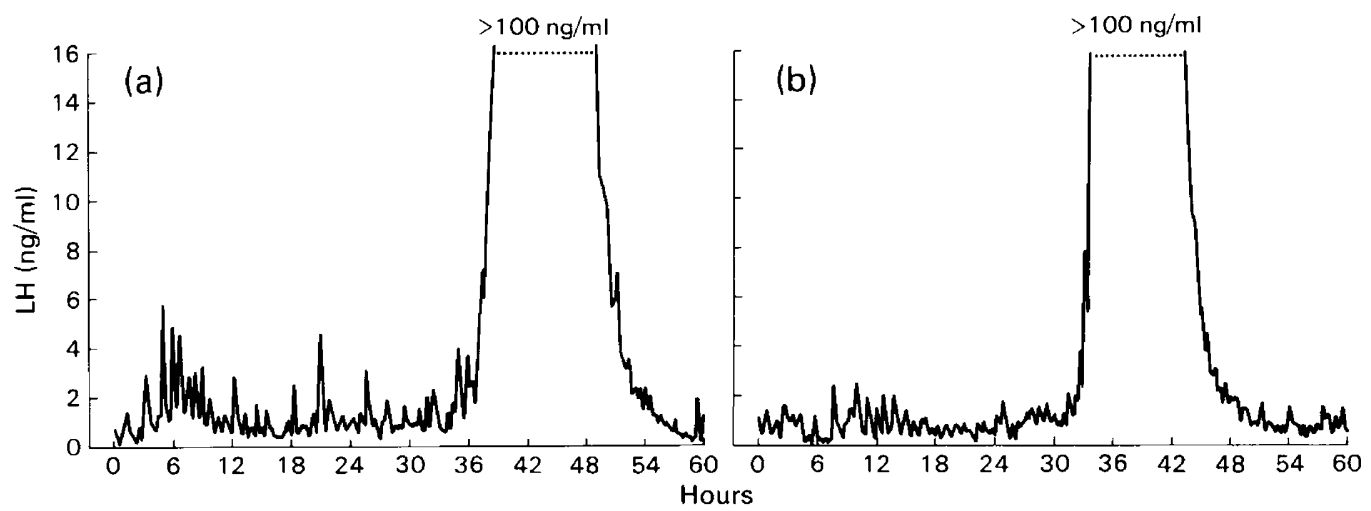

Text-fig. 6. LH concentrations in a ewe fed a diet of (a) wheaten chaff or (b) wheaten chaff supplemented with lupin grain. At the oestrous cycles immediately before and after the sampling period, the ewe in (a) had single ovulations and the ewe in (b) had twin ovulations. Each ewe was bled from an indwelling jugular catheter every $15 \mathrm{~min}$ for $60 \mathrm{~h}$, starting at the time of withdrawal of a progesterone-releasing implant. (Data from Radford et al., 1980.)

ewes were compared there was no apparent difference in LH pulse frequency or LH level during the period from progesterone implant removal to the onset of the LH surge. Levels of FSH over this same period were slightly lower in ewes with twin ovulations, presumably due to increased negative feedback of oestrogens in these animals. There was a large between-animal variance and the differences were not statistically significant.

\section{Hormone levels in ewes immunized against steroids}

The levels of gonadotrophins in ewes immunized against androgens and oestrogens have been extensively reported (Scaramuzzi, 1979; Martensz et al., 1976; Martensz \& Scaramuzzi, 1979; Martensz, Scaramuzzi \& Van Look, 1979). In summary, these results show an increased frequency of pulsatile LH release. The patterns of FSH levels were more variable with decreased levels (androstenedione-immunized), unchanged levels (testosterone-immunized), or increased levels (oestrone- and oestradiol-17 $\beta$-immunized) reported. As all of these treatments lead to increases in ovulation rate these data leave a confused picture as to the role of gonadotrophins in regulation of ovulation rate.

\section{Inhibin}

Inhibin is a partly characterized peptide produced by the granulosa cells and present in high concentrations in follicular fluid. Inhibin levels have been determined in the cytosol fraction of whole ovary homogenates from Booroola and control ewes (Cummins, O'Shea, Bindon, Lee \& Findlay, 1983). These measures indicate that the Booroola ewe has a lower content of inhibin in its ovaries. Taken together with the known effects of bovine follicular fluid in delaying ovulation in the ewe (Cummins, Bindon, O'Shea \& Piper, 1980) the findings suggest that inhibin may be involved in regulating ovulation rate. When Merino ewes were immunized against a purified preparation of bovine follicular inhibin (O'Shea, Cummins, Bindon \& Findlay, 1982) ovulation rates were increased. All of these data therefore suggest that inhibin is in some way involved in the regulation of ovulation rate, and that the inhibin-immune ewe has deregulated her follicle maturation processes and hence ovulation rate. We know that exogenous inhibin (given as bovine follicular fluid) can depress FSH levels, but not LH levels, in ewes (Findlay, Cummins, O'Shea \& Bindon, 1981). The question still remains, however, of whether inhibin is acting by controlling FSH 
levels, as suggested by Goodman, Pickover \& Karsch (1981), or is exerting some direct action on follicles in the ovary.

\section{Conclusions}

The data presented in the 3 preceding sections are in agreement with a much larger body of data which has in general failed to find hormonal correlates of ovulation rate (Brien, Baxter, Findlay \& Cumming, 1976; Findlay \& Cumming, 1976; Scaramuzzi \& Land, 1978; Bindon, Blanc, Pelletier, Terqui \& Thimonier, 1979; Haresign, 1981; Bindon, Findlay \& Piper, 1982). It can therefore be stated with some confidence that the principal reproductive hormones thought to be involved in the control of ovulation rate are not consistently different in ewes with wide differences in ovulation rate. The widely assumed quantitative role of the reproductive hormones, especially $\mathrm{FSH}$, in regulating ovulation rate must be questioned. The most favoured current explanation is that our methodology for measuring such hormones as oestradiol and FSH are deficient in detecting the probably small differences $(\approx 10 \%)$ needed to change ovulation rate (Brown, 1978) or that the antiFSH sera used in our assay systems do not accurately reflect the biological activity of FSH in highly fecund sheep (B. M. Bindon, personal communication). Another explanation is that ovulation rate is not hormonally regulated. It cannot be disputed that the growing follicle has an absolute requirement for gonadotrophic hormones without which ovulation is not possible, but it does not necessarily follow that these same hormones regulate the number of follicles that normally mature and ovulate. It remains to be shown that ovulation rate (as distinct from the induction of superovulation using FSH; see Wright et al., 1981)) can be increased by short-term (over 6 days) administration of gonadotrophins to the breeding ewe. Our own attempts to do this have been confined to LH and have produced equivocal results (H. M. Radford \& R. J. Scaramuzzi, unpublished data). When Merino ewes were given hourly pulses of an ovine LH preparation $(20 \mu \mathrm{g} / \mathrm{pulse}$; pulse amplitude of $\approx 10 \mathrm{ng} / \mathrm{ml})$ during the follicular phase of the oestrous cycle, ovulation rate was marginally increased. Other experiments in which GnRH pulses were given to ewes in larger groups did not produce increases in ovulation rate (G. B. Martin \& D. Clapin, unpublished data). It has been reported that FSH administered to anoestrous sheep in conjunction with LH induced ovulation and increased ovulation rate (B. Oussaid, Y. Cognie \& N. Poulin, unpublished data). However, a similar effect of FSH in sheep undergoing normal oestrous cycles remains to be demonstrated.

\section{Patterns of follicular growth}

Whatever it is that regulates ovulation rate must finally be seen in the pattern of follicular growth and maturation. Extensive morphological studies of follicle populations in sheep with genetically determined differences in ovulation rate have been reported (Turnbull, Braden \& Mattner, 1977; Turnbull, Mattner, George \& Scaramuzzi, 1978; Cahill, Mariana \& Mauléon, 1979; Cahill, 1981). The distribution of follicle populations in Romanov sheep shows them to have increased numbers of antral follicles and decreased numbers of primordial follicles. Likewise the Booroola Merino normally also has a larger number of antral follicles and reduced numbers of primordial follicles (Cahill et al., 1982). However, K. E. Turnbull \& R. J. Scaramuzzi (unpublished) have described a small group of aged (8-year-old) Booroola ewes that were able to maintain their ovulation rate despite a greatly reduced number of antral follicles (Table 6). It would therefore seem that follicle number, a measure of the turnover of follicles within the ovary, is not a determinant of ovulation rate in so far as other mechanisms can compensate for very low rates of turnover in the population of growing follicles. It seems obvious that such a compensatory mechanism must involve a reduced rate of atresia and, in extreme cases, an almost total conservation of the growing follicle population. 
Table 6. The total number of follicles in the rapid growth phase (normal and atretic) and corpora lutea in the ovaries of 5 aged Booroola Merino ewes (K. E. Turnbull \& R. J. Scaramuzzi, unpublished data)

\begin{tabular}{cccc}
\hline \multicolumn{2}{c}{$\begin{array}{c}\text { Total no. of follicles } \\
\text { Class } 4 \text { and above }\end{array}$} \\
\cline { 2 - 3 } & & $\begin{array}{c}\text { Early } \\
(\sim 0.35 \mathrm{~mm} \text { diameter and above })\end{array}$ & $\begin{array}{c}\text { No. } \\
\text { of } \\
\text { corpora } \\
\text { lutea }\end{array}$ \\
\cline { 2 - 3 } & Normal & atresia & \\
\hline 7496 & 23 & 2 & 2 \\
7497 & 24 & 1 & 3 \\
7224 & 15 & 8 & 4 \\
7185 & 100 & 20 & 4 \\
\hline
\end{tabular}

Follicle classes, the rapid growth phase and early atresia are defined according to Turnbull et al. (1977).

The patterns of atresia appear to be different in the high-fecundity breeds. Atresia appears earlier (Text-fig. 7), and while the total incidence of atresia varies very widely and seems more likely to be related to follicle number (Text-fig. 8) rather than ovulation rate per se, this pattern of distribution is consistent with the suggestion of earlier maturation of follicles in highly fecund sheep (R. J. Scaramuzzi, J. A. Downing \& K. E. Turnbull, unpublished). The preovulatory follicle of the Booroola Merino is much smaller than the preovulatory follicle of control Merinos (Baird, Ralph, Seamark, Amato \& Bindon, 1982) and develops responsiveness to hCG sooner (R. J. Scaramuzzi, K. E. Turnbull \& B. M. Bindon, unpublished data), therefore having fewer granulosa cells when mature and smaller corpora lutea (Scaramuzzi, Turnbull, Downing \& Bindon, 1981a).

So it appears likely that, in the Booroola Merino, the early maturation of the preovulatory follicle, paralleled by the earlier appearance of other markers of follicular growth, antrum formation, and the onset of atresia, is in part responsible for the increased ovulation rate of this strain. Why these follicles mature sooner and what part the various reproductive hormones discussed earlier play remain to be answered.

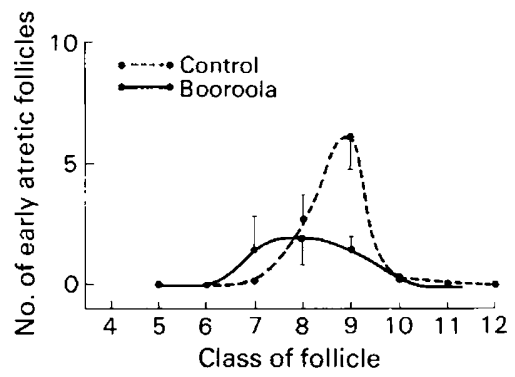

Text-fig. 7. The class distribution of early atretic follicles in Booroola Merino and control ewes. (R. J. Scaramuzzi \& K. E. Turnbull, unpublished data.) Follicle classes and early atresia are defined according to Turnbull et al. (1977). 


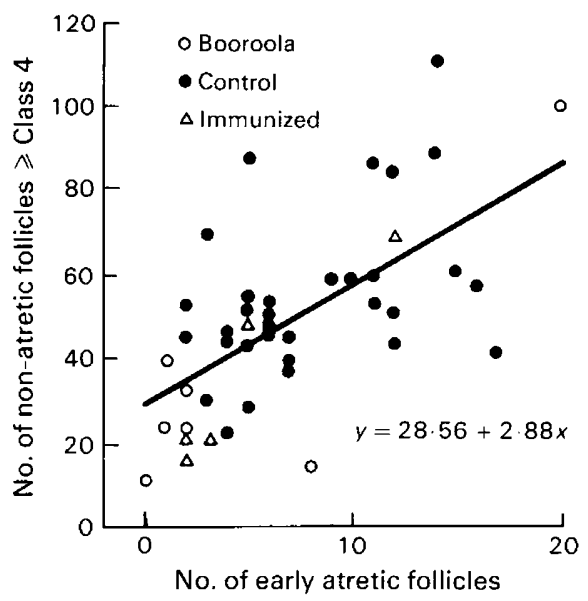

Text-fig. 8. The relationship between the number of non-atretic follicles in the rapid growth phase and the number of early atretic follicles in Booroola Merino ewes, control Merino ewes and Merino ewes immunized against androstenedione-11-BSA. (R. J. Scaramuzzi \& K. E. Turnbull, unpublished data.) The rapid growth phase, follicular class, and early atresia are defined according to Turnbull et al. (1977).

\section{General conclusion}

The determined efforts to find correlations between reproductive hormones and ovulation rate have produced generally negative results. This leads to the suggestion that ovulation rate, while hormone-dependent in as much as that ovulation must occur before its rate can be expressed, may be determined by non-endocrine intraovarian mechanisms. This may well be the situation in the Booroola Merino in which early maturation of Graafian follicles has been implicated as the cause of its high ovulation rate (R. J. Scaramuzzi, J. A. Downing \& K. E. Turnbull, unpublished). However, we cannot assume that the scheme proposed to account for the high ovulation rate of the Booroola necessarily applies to the other genetic or environmental means of increasing ovulation rate. If this were the case we would expect no additive effects of these methods. However, it is known that the highly fecund animal will respond to PMSG (Bindon \& Piper, 1982; Hoskinson, Hinks \& Scaramuzzi, 1982a) and to feeding (Allison \& Kelly, 1979), all of which suggest more than one mechanism being involved in the final determination of ovulation rate. Very little is known of the effect of these factors on follicular growth and development and it would appear to be a worthwhile area for further research.

Any model for the regulation of ovulation rate must take account not only of the range of factors which are known to influence it but also the possible range of effects of any one factor.

The assistance of Mr J. A. Downing, Mr K. E. Turnbull and Mr J. A. Avenell is gratefully acknowledged.

\section{References}

Allison, A.J. \& Kelly, R.W. (1979) Effects of differential nutrition on the incidence of oestrus and ovulation rate in Booroola X Romney and Romney ewes. Proc. N.Z. Soc. Anim. Prod. 39, 43-49.

Asdell, S.A. (1964) Patterns of Mammalian Reproduction, 2nd edn. Cornell University Press, Ithaca.
Baird, D.T. \& McNeilly, A.S. (1981) Gonadotrophic control of follicular development and secretion in the sheep oestrous cycle. J. Reprod. Fert., Suppl. 30, 119133.

Baird, D.T., Burger, P.E., Heavon-Jones, G.D. \& Scaramuzzi, R.J. (1974) The site of secretion of 
androstenedione in non-pregnant women. $J$. Endocr. 63, 201-212.

Baird, D.T., Ralph, M.M., Seamark, R.F., Amato, F. \& Bindon, B.M. (1982) Pre-ovulatory follicular activity and estrogen secretion of high (Booroola) and low fecundity Merino ewes. Proc. Aust. Soc. Reprod. Biol. 14, 83, Abstr.

Bindon, B.M. \& Piper, L.R. (1982) Physiological characteristics of high fecundity sheep and cattle. Proc. 2nd Wld Congr. Sheep and Beef Cattle Breeding, pp. 315332. Eds R. A. Barton \& W. C. Smith.

Bindon, B.M., Thimonier, J. \& Piper, L.R. (1978) Timing of the pre-ovulatory LH discharge in high fecundity sheep. Proc. Aust. Soc. Reprod. Biol. 10, 82, Abstr.

Bindon, B.M., Blanc, M.R., Pelletier, J., Terqui, M. \& Thimonier, J. (1979) Periovulatory gonadotrophin and ovarian steroid patterns in sheep of breeds with differing fecundity. J. Reprod. Fert. 55, 15-25.

Bindon, B.M., Findlay, J.K. \& Piper, L.R. (1982) Preovulatory plasma FSH in high fecundity Booroola ewes. Proc. Aust. Soc. Reprod. Biol. 14, 84, Abstr.

Bondioli, K.R. \& Wright, R.W., Jr (1981) Superovulation of goats with FSH or FSH + LH following synchronization of estrus. Theriogenology 15, 118.

Bradford, G.E., Quirke, J.F. \& Hart, R. (1971) Natural and induced ovulation rate of Finnish Landrace and other breeds of sheep. Anim. Prod. 13, 627-635.

Brien, F.D., Baxter, R.W., Findlay, J.K. \& Cumming, I.A. (1976) Effect of lupin grain supplementation on ovulation rate and plasma follicle stimulating hormone (FSH) concentration in maiden and nature Merino ewes. Proc. Aust. Soc. Anim. Prod. 10, $237-$ 240.

Brown, J.B. (1978) Pituitary control of ovarian function-concepts derived from gonadotrophin therapy. Aust. \& N.Z. Jl Obstet. Gynaec. 18, 46-54.

Cahill, L.P. (1981) Folliculogenesis in the sheep as influenced by breed, season and oestrous cycle. $J$. Reprod. Fert., Suppl. 30, 135-142.

Cahill, L.P., Mariana, J.C. \& Mauléon, P. (1979) Total follicular populations in ewes of high and low ovulation rates. J. Reprod. Fert. 55, 27-36.

Cahill, L.P., Loel, T.A., Turnbull, K.E., Piper, L.R., Bindon, B.M. \& Scaramuzzi, R.J. (1982) Follicle populations in strains of Merino ewes with high and low ovulation rates. Proc. Aust. Soc. Reprod. Biol. 14, 76, Abstr.

Coop, I.E. (1966) Effect of flushing on reproductive performance of ewes. J. agric. Sci., Camb. 67, 305323.

Cox, R.I., Wilson, P.A., Scaramuzzi, R.J., Hoskinson, R.M., George, J.M. \& Bindon, B.M. (1982) The active immunization of sheep against oestrone, androstenedione, or testosterone to increase twinning. Proc. Aust. Soc. Anim. Prod. 14, 511-514.

Cumming, I.A. (1977) Relationships in the sheep of ovulation rate with liveweight, breed, season and plane of nutrition. Aust. J. exp. Agric. Anim. Husb. 17, 234-241.

Cummins, L.J., Bindon, B.M., O'Shea, T. \& Piper, L.R. (1980) Effects of ovine follicular fluid given during induced luteolysis in control and Booroola Merinos. Proc. Aust. Soc. Reprod. Biol. 12, 50, Abstr.

Cummins, L.J., O'Shea, T., Bindon, B.M., Lee, V.W.K. \& Findlay, J.K. (1983) Ovarian inhibin content and sensitivity to inhibin in Booroola and control strain Merino ewes. J. Reprod. Fert. 67, 1-7.

Dun, R.B., Ahmed, W. \& Morrant, A. J. (1960) Annual reproductive rhythm in Merino sheep related to the choice of mating time at Trangie, Central Western New South Wales. Aust. J. Agric. Res. 11, 805825.

Findlay, J.K. \& Cumming, I.A. (1976) FSH in the ewe: Effects of season, live weight and plane of nutrition on plasma FSH and ovulation rate. Biol. Reprod. 15, 335-342.

Findlay, J.K., Cummins, L., O'Shea, T. \& Bindon, B. (1981) Suppression of plasma FSH in ovariectomized ewes given follicular fluid. Proc. Aust. Soc. Reprod. Biol. 13, 34, Abstr.

Fletcher, I.C. (1971) Effects of nutrition, liveweight and season on the incidence of twin ovulation in South Australian strong-wool Merino ewes. Aust. J. Agric. Res. 22, 321-330.

Fletcher, I.C. (1974) An effect of previous nutritional treatment on the ovulation rate of Merino ewes. Proc. Aust. Soc. Anim. Prod. 10, 261-264.

Fletcher, I.C., Geytenbeek, P. \& Allden, W.G. (1970) Interaction between the effects of nutrition and season of mating on reproductive performance in crossbred ewes. Aust. J. exp. Agric. Anim. Husb. 10, 393-396.

Gherardi, P.B. \& Lindsay, D.R. (1980) The effect of season on the ovulatory response of Merino ewes to serum from pregnant mares. J. Reprod. Fert. 60, 425 429.

Goodman, R.L. \& Karsch, F.J. (1981) A critique of the evidence on the importance of steroid feedback to seasonal changes in gonadotrophin changes. $J$. Reprod. Fert., Suppl. 30, 1-13.

Goodman, R.L., Pickover, S.M. \& Karsch, F.J. (1981) Ovarian feedback control of follicle-stimulating hormone in the ewe. Evidence for selective suppression. Endocrinology 108, 772-777.

Gunn, K.G. \& Doney, J.M. (1979) Fertility of Cheviot ewes. I. The effect of body condition at mating on ovulation rate and early embryo mortality in north and south Cheviot ewes. Anim. Prod. 29, 11-16.

Guo, Z.-Q., Ding, H., Shi, M.-Y., Zeng, G.-Q., Jiang, G.-T., Wang, H.-Y., Xu, Y.-S. \& Zhu, C. (1981) Serum progesterone, LH and estradiol-17 $\beta$ levels throughout the oestrous cycle in Chinese $\mathrm{Hu}$ and Karakul sheep with different ovulation rates. Chin. agric. Sci. 4, 1721. [In Chinese.]

Hanrahan, J.P. (1980) Ovulation rate as the selection criterion for litter size in sheep. Proc. Aust. Soc. Anim. Prod. 13, 405-408.

Haresign, W. (1981) Influence of nutrition on reproduction in the ewe. I. Effects on ovulation rate, follicle development and luteinizing hormone release. Anim. Prod. 32, 197-202.

Hoskinson, R.M., Hinks, N.T. \& Scaramuzzi, R.J. (1982a) Effects of PMSG on ovulation rate in the oestrone-immunized ewe. Proc. Aust. Soc. Reprod. Biol. 14, 93, Abstr.

Hoskinson, R.M., Scaramuzzi, R.J., Downing, J.A., Hinks, N.T.\& Turnbull, K.E. (1982b) Observations of oestrus and ovulation in ewes actively immunized against progesterone. Proc. Aust. Soc. Reprod. Biol. 14, 92, Abstr. 
Knight, T.W., Oldham, C.M. \& Lindsay, D.R. (1975) Studies in ovine infertility in agricultural regions in Western Australia: the influence of a supplement of lupins (Lupinus angustifolius cv Uniwhite) at joining on the reproductive performance of ewes. Aust. J. Agric. Res. 26, 567-575.

Lahlou-Kassi, A. \& Marie, M. (1981) A note on ovulation rate and embryonic survival in D'man ewes. Anim. Prod. 32, 227-229.

Land, R.B. (1976) The sensitivity of the ovulation rate of Finnish Landrace and Blackface ewes to exogenous oestrogen. J. Reprod. Fert. 48, 217-218.

Land, R.B. (1977) Genetic variations and improvement. In Reproduction in Domestic Animals, 3rd edn, pp. 577-604. Eds H. H. Cole \& P. T. Cupps. Academic Press, New York.

Land, R.B., Pelletier, J., Thimonier, J. \& Mauléon, P. (1973) A quantitative study of genetic differences in the incidence of oestrus, ovulation and plasma luteinizing hormone concentration in the sheep. $J$. Endocr. 58, 305-315.

Land, R.B., Morris, B.A., Baxter, G., Fordyce, M. \& Forster, J. (1982) The improvement of sheep fecundity by treatment with antisera to gonadal steroids. J. Reprod. Fert. 66, 625-634.

Laster, D.B. (1973) Ovulation, fertility and prenatal mortality in heifers treated with PMSG or porcine FSH. J. Reprod. Fert. 33, 275-282.

Lindsay, D.R. (1976) The usefulness to the animal producer of research findings in nutrition on reproduction. Proc. Aust. Soc. Anim. Prod. 9, 217224.

Marshall, F.H.A. (1903) The oestrous cycle and formation of the corpus luteum in the sheep. Phil. Trans. $R$. Soc. $B$ 196, 47-96.

Martensz, N.D. (1977) The experimental manipulation of gonadotrophins in non-pregnant sheep by immunization against steroid hormones. Ph.D. thesis, University of Edinburgh.

Martensz, N.D. \& Scaramuzzi, R.J. (1979) The plasma concentrations of luteinizing hormone, folliclestimulating hormone and progesterone during the breeding season in ewes immunized against androstenedione or testosterone. $J$. Endocr. 81, 249259.

Martensz, N.D., Baird, D.T., Scaramuzzi, R.J. \& Van Look, P.F.A. (1976) Androstenedione and the control of luteinizing hormone in the ewe during anoestrus. $J$. Endocr. 69, 227-237.

Martensz, N.D., Scaramuzzi, R.J. \& Van Look, P.F.A. (1979) The plasma concentrations of luteinizing hormone and follicle-stimulating hormone during anoestrus in ewes actively immunized against oestradiol-173, oestrone or testosterone. J. Endocr. 81, 261-269.

Martin, G.B. \& Scaramuzzi, R.J. (1983) The induction of oestrus and ovulation in seasonally anovular ewes by exposure to rams. J. Steroid Biochem. 19 (In press).

McKenzie, F. \& Terrill, C.E. (1937) Oestrus, ovulation and related phenomena in the ewe. Res. Bull. Mo. Agric. Exp. Stn No. 264.

Moore, N.W. \& Shelton, J.N. (1964) Response of the ewe to a horse anterior pituitary extract. J. Reprod. Fert. 7, 79-87.
Morley, F.H.W., White, D.H., Kenney, P.A. \& Davis, I.F. (1978) Predicting ovulation rate from live weight in ewes. Agricultural Systems 3, 27-45.

Oldham, C.M. (1980) A study of sexual and ovarian activity in Merino sheep. Ph.D. thesis, University of Western Australia.

O'Shea, T., Cummins, L.J., Bindon, B.M. \& Findlay, J.K. (1982) Increased ovulation rate in ewes vaccinated with an inhibin enriched fraction from bovine follicular fluid. Proc. Aust. Soc. Reprod. Biol. 14, 85, Abstr.

Quirke, J.F. (1978) Reproductive performance of Galway, Finnish Landrace and Finncross ewe lambs. Ir. J. Agric. Res. 17, 25-37.

Quirke, J.F. (1979) Effect of body weight in the attainment of puberty and reproductive performance of Galway and Fingalway female lambs. Anim. Prod. 28, 297-307.

Radford, H.M. (1959) Variation in the incidence of twin ovulation in Merino ewes on a constant plane of nutrition. Aust. J. Agric. Res. 10, 377-386.

Radford, H.M., Donegan, S. \& Scaramuzzi, R.J. (1980) The effect of supplementation with lupin grain on ovulation rate and plasma gonadotrophin levels in adult Merino ewes. Proc. Aust. Soc. Anim. Prod. 13, 457, Abstr.

Reeve, J.L. \& Chamley, W.A. (1982) Reliable breeding of Border Leicester $\times$ Merino ewes in spring using progesterone in association with the "ram effect". Proc. Aust. Soc. Reprod. Biol. 14, 89, Abstr.

Robinson, T.J. (1951) The control of fertility in sheep. Part II. The augmentation of fertility by gonadotrophin treatment of the ewe in the normal breeding season. J. agric. Sci., Camb. 41, 6-63.

Robinson, T.J. (1954) Necessity for progesterone with estrogen for the induction of recurrent estrus in the ovariectomized ewe. Endocrinology 55, 403-408.

Scaramuzzi, R.J. (1976) Physiological effects of immunizing sheep against oestradiol-173. In Physiological Effects of Immunity against Reproductive Hormones, pp. 67-90. Eds R. G. Edwards \& M. H. Johnson. Cambridge University Press.

Scaramuzzi, R.J. (1979) Antibodies to androgens, and ovulation in the ewe. J. Steroid Biochem. 11, 957-961.

Scaramuzzi, R.J. \& Land, R.B. (1978) Oestradiol levels in sheep during the oestrous cycle: a comparison of breeds of different fecundity. J. Reprod. Fert. 53, $167-171$

Scaramuzzi, R.J., Davidson, W.G. \& Van Look, P.F.A. (1977) The effect of active immunization against androstenedione on oestrus and ovulation in sheep. Nature, Lond. 269, 817-818.

Scaramuzzi, R.J., Martensz, N.D. \& Van Look, P.F.A. (1980a) Ovarian morphology and the concentrations of steroids, and of gonadotrophins during the breeding season in ewes actively immunized against oestradiol-17 $\beta$ or oestrone. J. Reprod. Fert. 59, 303310 .

Scaramuzzi, R.J., Baird, D.T., Clarke, I.J., Martensz, N.D. \& Van Look, P.F.A. (1980b) Ovarian morphology and the concentration of steroids during the oestrous cycle of sheep actively immunized against androstenedione. J. Reprod. Fert. 58, 27-35.

Scaramuzzi, R.J., Turnbull, K.E., Downing, J.A. \& Bindon, B.M. (1981a) Luteal size and functions in the 
Booroola Merino. Proc. Aust. Soc. Reprod. Biol. 13, 77, Abstr.

Scaramuzzi, R.J., Baird, D.T., Martensz, N.D., Turnbull, K.E. \& Van Look, P.F.A. (1981 b) Ovarian function in the ewe after active immunization against testosterone. J. Reprod. Fert. 61, 1-9.

Scaramuzzi, R.J., Cox, R.I. \& Hoskinson, R.M. (1982) The use of an immunological method to increase twinning in sheep. Proc. 2nd Wld Congr. Sheep and Beef Cattle Breeding, pp. 359-364. Eds R. A. Barton \& W. C. Smith.

Smith, J.F., Jagusch, K.T., Brunswick, L.F.C. \& Kelly, R.W. (1979) Coumestans in lucerne and ovulation in ewes. N.Z. Jl Agric. Res. 22, 411-416.

Smith, J.F., Jagusch, K.T. \& Farquhar, P.A. (1981) Protein intake and multiple ovulation in ewes. Proc. Aust. Soc. Reprod. Biol. 13, 6, Abstr.

Turnbull, K.E., Braden, A.W.H. \& Mattner, P.E. (1977) The pattern of follicular growth and atresia in the ovine ovary. Aust. J. biol. Sci. 30, 229-241.
Turnbull, K.E., Mattner, P.E., George, J.M. \& Scaramuzzi, R.J. (1978) The relation between patterns of ovarian follicle growth and ovulation rate in sheep. Aust. J. biol. Sci. 31, 649-655.

Underwood, E.J., Shier, F.L. \& Davenport, N. (1944) Studies in sheep husbandry in W.A. V. The breeding season of Merino, crossbred and British Breed ewes in the agricultural districts. J. Agric. West. Aust. 11, Series 2, 135-143.

Walton, J.S., McNeilly, J.R., McNeilly, A.S. \& Cunningham, F.J. (1977) Changes in concentrations of follicle-stimulating hormone, luteinizing hormone, prolactin and progesterone in the plasma of ewes during the transition from anoestrus to breeding activity. $J$. Endocr. 75, 127-136.

Wright, R.W., Jr, Bondioli, K., Grammer, J., Kuzan, F. \& Menino, A., Jr (1981) FSH or FSH plus LH superovulation in ewes following estrus synchronization with medroxyprogesterone acetate pessaries. J. Anim. Sci. 52, 115-118. 